\title{
Citizen Kane: The inadequacies of the 'Rosebud' ending
}

\section{Stephanie Gajewski}

Citizen Kane by Orson Welles presents a hollow ending to a complex film. While Rosebud exists as numerous entities throughout the film, as Kane's last words, the film's narrative structure and one of the two leading interpretations of the film, whether the ending is satisfying rests upon whether the viewer believes the reveal of Rosebud as Kane's childhood sleigh 'solves' the 'narrative' of Citizen Kane. However, as Roger Ebert notes in his commentary on Citizen Kane, 'you have to be an active viewer when you look at Citizen Kane'. ${ }^{1}$ When a viewer reads the film holistically and without the intention of interpreting Kane's life, Rosebud is ultimately an artificial deduction that can only be made by the audience based on the narrative structure of the film, described by Pauline Kael as 'gimmickry'. ${ }^{2}$ Therefore, the Rosebud ending to Citizen Kane cannot be satisfying and is hinging too much on too little for two primary reasons. Firstly, while the film does create some basis for the 'Rosebud interpretation', it also creates an arguably stronger foundation for the alternate theory: the 'Enigma interpretation'. ${ }^{3}$ Secondly, the ethos and narrative structure of Citizen Kane deny the viewer a definitive answer to what the audience believes to be the objective of the film; as the film and audience violate the rights

\footnotetext{
1 Commentary with Roger Ebert, Citizen Kane, directed by Orson Welles (1941. Burbank, CA: Turner Entertainment Co, 2001), DVD.

2 Pauline Kael, 'Raising Kane', The New Yorker, February 20 and 27, 1971.

3 Noël Carroll, 'Interpreting Citizen Kane' in Interpreting the Moving Image, Cambridge Studies in Film Series (Cambridge University Press, 1998), 153-65.
} 
of its characters and assume at its core Citizen Kane is about finding a singular, definitive answer to explain the motivations and life of Charles Foster Kane.

Laura Mulvey's 'Citizen Kane' notes Noël Carroll was the first to establish the two disconnected leading critical responses to Citizen Kane; the 'Rosebud interpretation' and the 'Enigma interpretation'. ${ }^{4}$ The 'Rosebud interpretation' entirely rests on the viewer putting together images from the film, which Mulvey notes are typically 'patterns, symmetries and repetitions'. ${ }^{5}$ The audience unites images through the narrative quest of Rosebud. One such image this could be used with is the snow globe that is shattered by Kane upon his death. ${ }^{6}$ This is directly associated with the scene where Kane is 'handed over' to Thatcher and reacts violently with the sled he was playing with. This allows the audience to associate Rosebud with Kane's childhood and mother through the symmetry between the idealistic snow globe and its reflection in the boarding house, which becomes apparent that this is 'something he lost'. ${ }^{7}$ The audience can make further assumptions through this idea of loss. In order to regain his childhood, Kane begins a quest of acquisitions extending to power, statues, newspapers and people. It's his acquisition of people that proves to ultimately be the most detrimental to Kane, highlighted by Kane's death and ending of the film. Welles uses extreme close ups on Kane and the snow globe to emphasise his loneliness at death. This is reversed in the ending, where Welles uses wide overhead shots and deep focus to allow the audience to see the piles upon piles of Kane's belongings. The circular, symmetrical narrative of the film and the Rosebud interpretation emphasises what he lost — Rosebud — and what he tried to fill the void with — items that held little value.

4 This text is part of the 'BFI Film Classics' book series and reads as an extended essay on Kane, like Kael's 'Raising Kane', albeit with a primary focus on critical analysis as opposed to a biased and ultimately discredited argument on auteurism and authorship. Laura Mulvey, 'Citizen Kane', BFI Film Classics Series (Palgrave Macmillan on behalf of the British Film Institute, 2012), 30; Carroll, 'Interpreting Citizen Kane', 153-65.

5 Mulvey, 'Citizen Kane', 55.

6 Robert L. Carringer, 'Rosebud, Dead or Alive: Narrative and Symbolic Structure in Citizen Kane', PMLA, Vol. 91, No. 2 (March 1976): 185-93, accessed 6 April 2015.

7 Citizen Kane, directed by Orson Welles (1941. Burbank, CA: Turner Entertainment Co, 2001), DVD. 
Despite the emphasis the film places on Rosebud, as the narrative drive and the seeming gravity this drive gives the Rosebud reveal to the audience, the film undercuts Rosebud. While introducing this narrative lens, Thompson's boss, Mr Rawlson, is backlit so sinisterly he looks devilish. ${ }^{8}$ Further, no character actually knows anything about Rosebud. The two primary characters who have a connection to it - Mr Thatcher and Susan, through the sled and the snow globe respectively - have no idea what it is. Mr Thatcher is dead and didn't note the name of the sled shoved into him by a young Kane, though he did understand its importance to Kane as a low shot shows Thatcher looming over Kane at Christmas after giving him a new sled. On the other hand, Susan didn't come into contact with Rosebud. Instead, it is her snow globe that Kane breaks at his death, a globe that's almost surreptitiously hidden in Susan's apartment as Kane and Susan are talking about their mothers, allowing the audience to link Susan to Kane as a part of his search for his childhood. Further, events in the film cause doubts over whether Kane's actions can be unified through Rosebud. Kane already has the love of the people, but when we're shown him running for higher office, he seems deluded in his own power, as shown by him standing in front of an overinflated image of himself. Further, he destroys the majority of his primary relationships that could substitute for the love he lost in his childhood.

While the structure of Citizen Kane suggests an emphasis on finding out Rosebud, in reality it presents a stronger argument for the second interpretation of Citizen Kane, the 'Enigma interpretation'. This interpretation suggests that Kane was ultimately a myriad of different people that cannot be unified by one single word, which is well supported by the film through 'witnesses' of Kane's life, each providing a different interpretation of him. ${ }^{9}$ Thatcher presents a negative view of his ward, Bernstein presents an idealistic view of his boss, Leland presents a disillusioned opinion of his former friend, Susan presents an image of a powerful ex-husband, and Raymond recalls a weakened employer. These contrasting views are visually represented in the image of Kane walking past a mirror in Xanadu, revealing multiple, fragmented Kanes as if they are walking beside him.

8 Commentary with Roger Ebert, Citizen Kane.
9 Ibid. 
However, the character who presents the strongest argument for the 'Enigma interpretation' is Thompson, who actively rallies against pursuing this line of questioning. In response to Rawlson's exclamation that Kane 'maybe ... told us all about himself on his deathbed', Thompson's response is simply, 'Maybe he didn't'. Thompson represents the audience in the film, providing the vessel needed to explore Kane's life. This representation is highlighted by the fact that his face is never fully seen in the film, emphasising his utilisation as a vessel. After interviewing all his witnesses, Thompson comes to the conclusion that he has been 'playing with a jigsaw puzzle', understanding there isn't a definitive answer to Kane. Carroll describes Kane as 'a mass of contradictions', and Rosebud doesn't make sense of these contradictions. ${ }^{10}$ Even if it is a representation of his lost childhood, the film doesn't need to reveal that the name of Kane's sled is Rosebud in order for it to be understood that he lost his childhood. It's already been shown through his acquisition of items that can only be fully shown at the end of the film by the camera in an extreme wide shot. Kane himself said when he first meets Susan, 'I was in search of my youth'. He seemingly finds it through his mothering relationship with Susan, attempting to assume the role of his and her mother, culminating in him dominating the frame and leaving her in his shadow. When asked what he finds out about Kane, Thompson replies, 'Not much, really'. In a film that is presumably about giving a definitive answer to the question of Kane himself, it never gives one. This asks the question: What is Citizen Kane about?

The ethos of Citizen Kane can be summarised by Newton's Third Law: 'for every action there is an equal and opposite reaction'. When charting the shifting power and control of Kane, for every rise there is an equal fall: he has and loses an empire, he has and loses the public and he has and loses people. It seems consistent that each character would be held to this same standard, including the audience, a character through Thompson. Ultimately, the audience and the film violates Kane by trespassing, even though the old, rusting sign on the tall, Gothic doors guarding Xanadu explicitly says not to. As the audience is led up Xanadu to meet its' master, a single light is framed in the same place in each shot, even in the reflection in the water - a guiding light through a decayed, extensive estate. ${ }^{11}$ While this represents how Kane is trapped within a place of his

10 Carroll, 'Interpreting Citizen Kane', 153-65.

11 Commentary with Roger Ebert, Citizen Kane. 
own creation, isolated from the world, it also represents how the audience is trapped within the film. Once the camera reaches the light, it goes out. With it goes the person who could answer all the film's questions - Kane himself. Mankiewicz and Welles could have found a way to include Kane's point of view - a diary like Thatcher's could easily have been written in - but instead Kane's story is told without his voice. The audience is further punished by being at the mercy of a circular narrative that simply provides recollections of Kane's life and doesn't answer Rawlson's statement of telling us 'not ... what he did' but 'who he was'. Rosebud becomes a deduction made because the film seemingly doesn't give closure, forcing the audience to create their own. An unbiased view of Kane isn't shown, emphasising how the narrative structure provides no definitive resolution. In fact, the closest the film gets to a self description from Kane is his statement of being an 'American', which, like Rosebud, only offers more questions than it does answers. Further, the story is told from the points of view of individuals who have already made up their minds about who Kane is to them, but not necessarily who Kane was. As Pedro Gonzalez notes, 'the inner life of private individuals ... can never be made truly explicit', particularly on the terms of the public and without the voice of the individual. ${ }^{12}$

Rosebud cannot be a satisfying ending, not only because of the contradictions the film makes, or the violations the film makes, or the narrative structure it employs, but because the answer to the question 'What is Citizen Kane about?' is not about finding an answer to Kane himself. David Thomson described Rosebud as 'a gesture ... a trick the magician has for keeping our gaze off his hands' ${ }^{13}$ Ultimately, this trick attempts to divert us from film reflecting reality. Cinema is rooted in a longing to visually reanimate life and its struggles, as do all expressions of art, and Citizen Kane illustrates the wonders and capacities that human beings have to achieve, fail, struggle , and ultimately go on with their lives. The characters within Citizen Kane need no explanation for who Kane ultimately was, as they all hold their own firm beliefs based on their experiences with him, just as the audience

12 Pedro Blas Gonzalez, 'Citizen Kane: Biography and the Unfinished Sentence', Senses of Cinema, accessed 6 April 2014, sensesofcinema.com/2010/feature-articles/citizen-kanebiography-and-the-unfinished-sentence/.

13 David Thomson, The Big Screen: The Story of the Movies and What They Did to Us (Penguin, 2012), 169. 
does with everyone in their lives. Citizen Kane represents a longing for film to provide answers where none exist, resulting in Rosebud's creation as a manifestation of an individual's inability to understand the reflection of life in cinema, as it's built up to be a magical place full of happy endings as opposed to often crushing realities. To some, an answer to Citizen Kane might provide a reflection of reality to them, but this ending, no matter what it is, will ultimately be incomplete as it doesn't have the input of the central piece to the puzzle. ${ }^{14}$

Even if one believes that the 'answer' to Citizen Kane is Rosebud, it cannot be satisfying. The last image inside Xanadu is of Rosebud burning. The narrative focus of Citizen Kane is revealed, and swiftly taken away and allows Rosebud to burn. This reveal is not climactic, it is hollow. The question to which Rosebud is seemingly the answer has already been told. While the film has chosen to centre itself around Rosebud, this centre is ultimately a 'fallacy'. ${ }^{15}$ The film returns to the image it opened on, the cold gates surrounding Xanadu and the warning of 'No Trespassing' remains, with only the emphasis of the film being a 'labyrinth without a centre' remaining. ${ }^{16}$ Like Thompson, the audience has learnt nothing about who Kane was, simply what he did. ${ }^{17}$ The contradictions, structure and ethos of the film doesn't allow Rosebud to be a satisfying ending, as even if one believes Citizen Kane needs to answer the questions of Kane, the 'Rosebud interpretation' still leaves questions behind.

\section{References}

Bazin, André and Bitsch, Charles. 'Interview with Orson Welles', Senses of Cinema, Issue 46 (March, 2008) (originally published by Cahiers $d u$ Cinéma, No. 48, June 1958). Accessed 6 April 2015. sensesofcinema. com/2008/the-new-wave-remembered-focus-on-charles-bitsch/orsonwelles-bazin-bitsch/.

14 'This is not to say the film holds that there is no possible interpretation of a human life ... the audience to determine'. Carroll, 'Interpreting Citizen Kane', 153-65.

15 Carringer, 'Rosebud, Dead or Alive', 185-93.

16 'Borges described Citizen Kane as a labyrinth without a centre.' Mulvey, 'Citizen Kane', 3.

17 Citizen Kane, directed by Orson Welles. 
Borges, Jorge Luis, Waldman, Gloria and Christ, Ronald. 'An Overwhelming Film', October, Vol. 15 (Winter, 1980): 12-14. Accessed 6 April 2015.

Castle, Robert. 'All the Citizen's Men: Kane as Welles; also America', Bright Lights Film Journal (July, 2004). Accessed 6 April 2015. brightlightsfilm. com/all-the-citizens-men-welles-citizen-kane/.

Carringer, Robert L. 'Rosebud, Dead or Alive: Narrative and Symbolic Structure in Citizen Kane', PMLA, Vol. 91, No. 2 (March, 1976): 18593. Accessed 6 April 2015.

Carroll, Noël, 'Interpreting Citizen Kane', Interpreting the Moving Image, Cambridge Studies in Film Series. (Cambridge University Press, 1998), 153-65.

Citizen Kane. Directed by Orson Welles. (1941. Burbank, CA: Turner Entertainment Co, 2001). DVD.

Commentary with Roger Ebert, Citizen Kane. Directed by Orson Welles. 1941. (Burbank, CA: Turner Entertainment Co, 2001). DVD.

Corrigan, Timothy and White, Patricia. The Film Experience: An Introduction. Third edition. (Bedford/St. Martin's, 2012).

Gonzalez, Pedro Blas. 'Citizen Kane: Biography and the Unfinished Sentence', Senses of Cinema, Issue 57 (December, 2010). Accessed 6 April 2014. sensesofcinema.com/2010/feature-articles/citizen-kanebiography-and-the-unfinished-sentence/.

Kael, Pauline. 'Raising Kane', The New Yorker, February 20 and 27, 1971.

Lamb, Robert Paul. “Citizen Kane' and the Quest for Kingship', Journal of American Studies, Vol. 19, No. 2 (August, 1985): 267-70. Accessed April 62015.

Marling, Karal Ann. 'Review of The Battle over Citizen Kane, produced by Thomas Lennon and Michael Epstein', The Journal of American History, Vol. 84, No. 3 (December, 1997): 1175-77. Accessed 6 April 2015.

Mulvey, Laura. 'Citizen Kane', BFI Film Classics Series. (Palgrave Macmillan on behalf of the British Film Institute, 2012). 
MERICI - VOLUME 1, 2015

Parkinson, David. History of Film. Second edition. (Thames \& Hudson, 2012).

Riedlinger, Michael C. 'Orson Welles - Painter', Senses of Cinema, Issue 53 (December, 2009). Accessed 6 April 2015. sensesofcinema.com/2009/ feature-articles/orson-welles-painter/.

Thomson, David. The Big Screen: The Story of the Movies and What They Did to Us. (Penguin, 2012). 
This text is taken from Merici, Volume 1, 2015, edited by Henry Poetrodjojo, Ilze Alexander and Lauren Prossor, published 2016 by ANU eView, The Australian National University, Canberra, Australia. 